\title{
Zdeněk Fibich, Jan Ludevít Procházka, and Early Performances of Fibich's Works
}

\author{
Jana Vojtěšková
}

This contribution is focused on two sources deposited in the Czech Museum of Music that document relations between Jan Ludevit Procházka and Zdeněk Fibich: a brief musical manuscript in Fibich's hand shown in Hudec's thematic catalogue as being missing, ${ }^{1}$ and a letter of Procházka pertaining thereto.

Dr. Jan Ludevít Procházka (1837-1888) was one of the major figures in Prague musical life during the 1860s and 1870s, ${ }^{2}$ a pupil and then friend of Bedrich Smetana who was active as a pianist, conductor, music critic, editor, organizer, pedagogue, and composer. Starting around 1860 he engaged in very intensive and multifaceted activities in Prague in which he persisted for two decades. Procházka established himself as an important music critic in Prague starting in November 1865, when he replaced Smetana as author of the music column in Národní listy [National News]. Five years later he founded the first musical journal in the Czech lands with a modern orientation: Hudebni listy [Musical News]. After another three years he founded the pro-Smetana periodical Dalibor, whose first two years (through 1874) he edited. Less well known is the fact that he also contributed to the music column of the German newspaper Politik. ${ }^{3}$ In 1863 Procházka was among the founders of the Umělecká beseda [Artists' Society], and as the executive

1 Vladimír Hudec, Zdeněk Fibich. Tematický katalog [Zdeněk Fibich: Thematic Catalogue] (Prague, 2001) (hereafter $T K$ ), p. 850.

2 Miroslav Černý, "Procházka, Jan Ludevít”, in: Gracian Černušák, Bohumír Štědroň, Zdenko Nováček (eds.), Ceskoslovenský hudební slovník osob a institucí [Czechoslovak Musical Dictionary of People and Institutions], Vol. 2 (Prague, 1965), p. 370. Marta Ottlová, "Procházka, Jan Ludevit', in: Ludwig Finscher (ed.), Die Musik in Geschichte und Gegenwart, Personenteil, Vol. 13 (Kassel, 2005), col. 955-956. Miloslav Nedbal (ed.): Ludevít Procházka. Slavná doba české hudby. Výbor z kritik a článků [Ludevit Procházka: The Golden Era of Czech Music. A Selection from His Reviews and Articles] (Prague, 1958).

3 This was in 1877, shortly before Procházka's departure for Hamburg. His reviews bore the insignia "P". 
officer of that organization's music section until 1875 he actively shared in all its events, many of which he himself initiated. Already in the case of the society's subscription concerts he helped Smetana with the programming and in procuring performing materials. In 1866 he founded the Artists' Society's mixed chorus, which he himself directed. ${ }^{4}$ Then as a new offering he introduced "historical concerts", to which in 1870 he added church music by his contemporaries, calling the concerts Musica sacra. Unfortunately the Artists' Society's mixed chorus was discontinued that year, and along with it the performances of historical music, remarkable for their time. We might mention that later on Fibich, too, organized historical concerts in the framework of the Artists' Society, and was certainly informed about Procházka's earlier events.

In 1871 Procházka founded the Volné hudební zábavy [Free Musical Entertainments], which were organizationally less demanding and focused on new songs and chamber works as well as arrangements of symphonic works for piano four hands. Procházka himself played piano, while his wife Marta shared in the performance of songs. During the 1870s Procházka's activities expanded into other spheres as well. In 1871 he was one of the founders of the Hudebni matice [Musical Fund] of the Artists' Society, which published piano-vocal reductions of Czech operas. Then in 1874 he and František Ladislav Rieger founded the music division of the Museum of the Kingdom of Bohemia, which became the foundation of the collections of today's Czech Museum of Music. And two years later he gave the impulse for the foundation of the Chamber Music Society, of which he was the executive officer until his departure for Hamburg.

Procházka's field of work narrowed in the second half of the 1870s. Smetana and Otakar Hostinský left Prague, and the periodical Dalibor folded. There was a worsening in Procházka's position as an employee of the City of Prague, which was led by the “Old Czech" party whereas Procházka was a "Young Czech". Under these circumstances Procházka and his family moved in 1879 to Hamburg, where his wife obtained a position with the opera company. In Hamburg Procházka became director of the Society of Musical Artists, a professor of piano at the conservatory, and owner of a prospering musical institute. He promoted Czech music intensively. As is well known, he acquainted residents of Hamburg with many works by Smetana, and the culminating fruit of his efforts was the performance of Smetana's opera Dvě vdovy [The Two Widows] by the Hamburg Opera on 28 December $1881 .{ }^{5} \mathrm{He}$ continued promoting Czech music in Dresden, where he and his family moved for one season because of an engagement obtained by his wife Marta. Then he returned to Hamburg. Procházka's work came to a close relatively early: he died in 1888 at the age of fifty-one.

Procházka made the acquaintance of Zdeněk Fibich soon after the latter's arrival in Prague in 1871. They met each other at concerts, in the theatre, in the music section of the Artists' Society, and also in Procházka's salon, where musical society gathered. It

4 Hanuš Jelínek (ed.), Padesát let Umělecké besedy [Fifty Years of the Artists' Society] 1863-1913 (Prague, Umělecká beseda, 1913), p. $319+$ LXXI.

5 On 26 December 1881 Smetana wrote a letter to Procházka concerning this performance. 
was in Procházka's presence that Fibich made the acquaintance of Otakar Hostinský, in early October 1871 according to Hostinský's reminiscences of Fibich. ${ }^{6}$ Procházka took a lively interest in new musical works. First they were played for small private audiences in the framework of the Artists' Society, then publicly in the "Free Musical Entertainments", which Procházka reviewed in Hudební listy. Already the first three of these events included new works by Fibich: on 27 November 1871 a trio from his opera Bukovín, on 10 December his song Prilitlo jaro zdaleka [Spring Flew in from Afar], and on 21 December (the last such event of the year) his overture to the drama Pražský Žid [The Prague Jew], played in a four-hand arrangement on the piano by Procházka and the composer.

Procházka also mediated Fibich's negotiations concerning his position as a teacher in schools in Vilnius, ${ }^{7}$ acquiring contacts with the Russian ministry of education through his work in establishing the Russian orthodox church in Prague where he served as director of singing. Late in 1873, while Fibich was living in Vilnius, two symphonic works of his had their world premieres in Prague: thanks to Procházka a philharmonic concert on 7 December included his first symphonic poem, Othello, ${ }^{8}$ and in a "Musical Entertainment" on 12 December Procházka and Jindřich Kàan played a four-hand arrangement of his symphonic poem Záboj, Slavoj a Luděk [Záboj, Slavoj, and Luděk], an analysis of which was published by V. J. Novotný in Dalibor. ${ }^{9}$ The program on 12 December also included a performance of Fibich's Jasná noc [Clear Night] for violin and piano by the concert master of the theatre orchestra Cantani and Procházka. The two sources deposited in the Czech Museum of Music that are the focus of this contribution come from precisely this time. First let us quote from Procházka's letter to Fibich, ${ }^{10}$ written on 26 December 1873 shortly after the above-mentioned premieres:

First of all I congratulate you on the wonderful, very flattering success achieved in the philharmonic concert by your Othello. Undoubtedly you have already received all the newspapers with reviews via Miss Hanušová. The effect on the entire audience was surprising. I myself was bothered a little by the frequent caesuras in thought and the generally epigrammatic elaboration of the basic motives. I regret that you could not hear the work yourself; you, too, would sense the need to

6 O. Hostinského Vzpominky na Fibicha [Otakar Hostinskýs Memories of Fibich] (Prague, 1909), p. 4.

7 Cf. Vladimír Hudec, Zdeněk Fibich (Prague, 1971), p. 36.

8 The score of which had already been published by Emanuel Starý.

9 The first orchestral performance was given on 25 May 1874 by the Academic Readers' Society in the New Town Theatre, conducted by Adolf Čech. Hostinský published a review in Lumirr, saying: "Fibich's Záboj is the best orchestral work by him that we know."

10 Deposited in the Czech Museum of Music (part of the National Museum) under shelf mark CัMH G 7096. It comes from the archive of Zdeněk Nejedlý and was purchased from an antiquarian dealer in 1971. This letter was not included in Artuš Rektorys (ed.), Zdeněk Fibich. Sborník dokumentů a studii o jeho životě a díle [Zdeněk Fibich. A Collection of Documents and Studies Concerning His Life and Work], two volumes (Prague, 1951-1952), which does include three other letters Procházka wrote to Fibich. 
change the orchestration of some passages. Your Záboj a Slavoj, which we (I and Mr. Kàan) performed in the most recent entertainment of the Artists' Society cum grandissimo applasu, has a completely different vital stream; here there is dramatic progress of thought and an effective culmination. I am certain that it will have double the success!

Procházka's review of Othello in Národní listy echoes the sentiments expressed in this letter. ${ }^{11}$ The letter also includes comments concerning the further dissemination of Fibich's work: "Mr. Kliebert borrowed your Záboj last week and played it in several places. Today my wife is singing songs of yours at the home of Dr. Vaniček: "Die Thräne" (Chamisso), "Ich wandre durch die Nacht"-and Heine's tragedy. From this you see that we are thinking of you all the time." ${ }^{2}$ The letter also mentions a symphonic poem Fibich intended to write-Jaroslav, based on the Dvưr Králové [Queens' Court] and Zelená Hora [Green Mountain] manuscripts. Fibich had apparently been corresponding with Procházka about this composition: "The score you promised me in your last letter [this letter of Fibich's is missing] has not arrived yet. Won't I see your Jaroslav soon? I'm as eager as a child! As soon as you're finished, arrange it for us immediately for four hands, and we'll play it everywhere." But Fibich did not actually compose this piece. All that has been preserved is a six-bar motive of Jaroslav already dedicated on 12 September 1873 "[...] in everlasting memory and dear remembrance to my benefactor and guide on the path of truth and beauty, Dr. Ludevít Procházka." ${ }^{13}$ This motive is shown in Hudec's thematic catalogue among the unrealized sketches, where its autograph is said to be missing. ${ }^{14}$

This autograph unknown to Hudec has in fact been preserved. It is found as the thirtyeighth item in an album of correspondence and commemorative musical manuscript notations pertaining to Ludevít Procházka acquired in 2003 by the Czech Museum of Music (as part of the National Museum). This album was part of the artistic collection of Bedřich Donebauer. In 1908 it was purchased in an auction by Richard Morawetz (1881-1965), who late in the 1930s emigrated to Canada to escape the Nazis. After World War II the album became part of the collections of the Literary Archive of the

11 Národní listy of 13 December 1873. Reprinted in: Miloslav Nedbal (ed.): Ludevít Procházka. Slavná doba české hudby. Výbor z kritik a článků (Prague, 1958), p. 94-95. Procházka’s opinions on this piece were in agreement with those of Hostinský.

12 Thränen, to a text by Adalbert von Chamisso, composed 25 September 1872. Autograph missing, TK 171/1. Ich wandre durch die stille Nacht, No. 2 from Frühlingsstrahlen, fourteen songs with piano accompaniment, Op. 36, composed 12 July 1870, revised 1891, to a text by Joseph von Eichendorff. Autograph missing, TK 300/2. Tragödie, No. 4 from Vier Balladen für mittlere Stimme mit Klavierbegleitung, Op. 7, to a text by Heinrich Heine, composed 1873, autograph missing, TK 181/4.

13 The original Czech: "Na věčnou pamět a milou vzpomínku svému přínivci a vůdci po cestě pravdy a krásy dr. Ludevítu Procházkovi."

14 A facsimile of the autograph notation of the motive is published in Artuš Rektorys (ed.), Zdeněk Fibich. Sborník dokumentũ a studií o jeho životě a díle (Prague, 1951-1952), Vol. 2, p. 482. Cf. also Dalibor, 2 (1874), p. 15. 
National Museum, then the Literary Archive of the Memorial of National Literature (both institutions in Prague). After the "Velvet Revolution" of 1989 it was restituted to Morawetz's heirs along with some of the other items from his collection. Then in 2003 it was purchased by the Czech Museum of Music (thus coming back to the National Museum) with funds from the Czech Ministry of Culture.

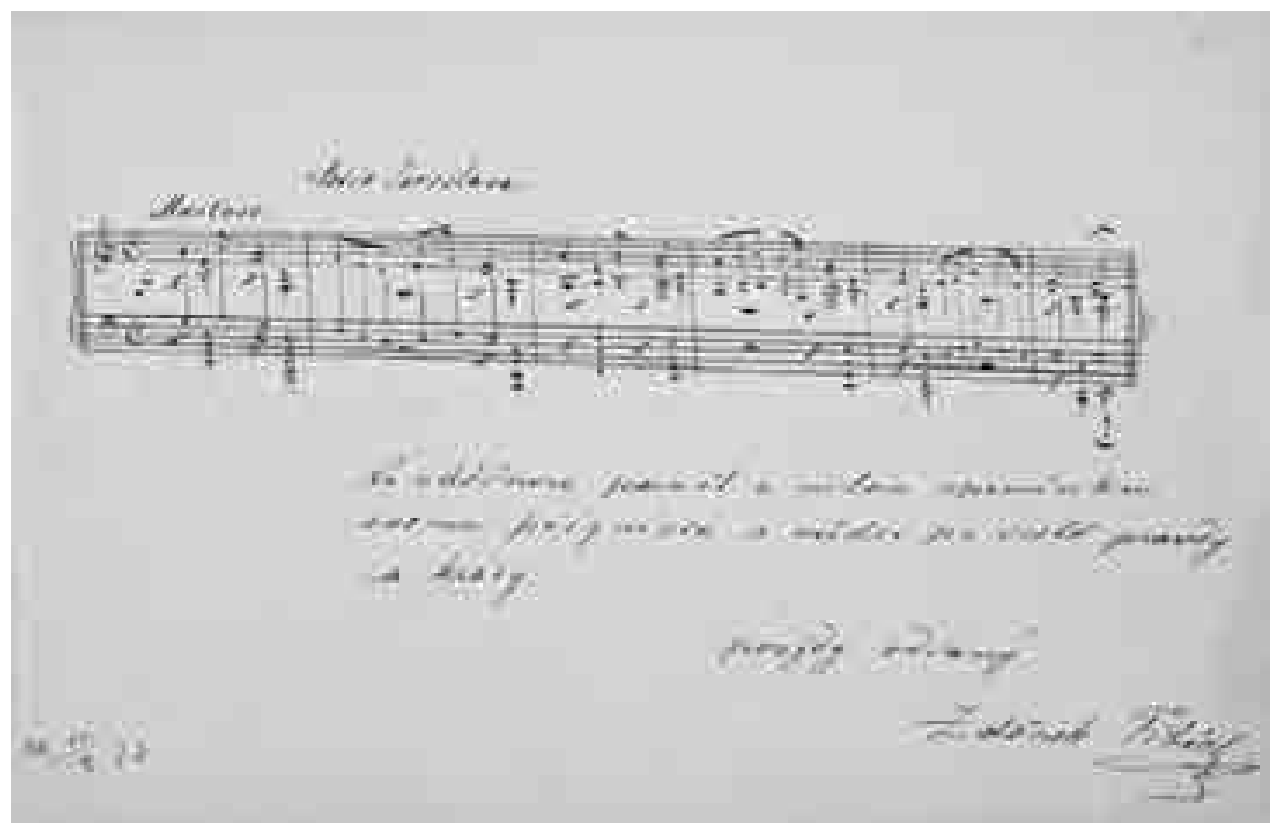

Zdeněk Fibich: Jaroslav (TK 503), Autograph, NM-ČMH shelf mark G 13627/38

Procházka corresponded with prominent figures in the musical world of his time. The album was probably assembled after his death, because it is arranged alphabetically according to the names of the writers, and thus the latest letter, written shortly before the end of Procházka's life, is placed in the middle of the album; if Procházka had pasted the letters into the album himself he would probably have done so chronologically, allowing him to add additional letters over time. Moreover, the list of contents at the end is not written in Procházka's hand. Whoever created the album chose letters from Procházka's extensive correspondence and arranged them in a memorial album with decorative binding. The intent was probably to show the breadth of Procházka's contacts, which extended far beyond the boundaries of the monarchy and included broad artistic circles. The album certainly does not contain all of Procházka's correspondence: it was intended as a representation. The topics of the letters are varied, pertaining to performance of musical works and containing information for musical periodicals that Procházka edited. There 
are also many commemorative notations of music by performers and composers with whom Procházka came into contact. ${ }^{15}$

The two sources pertaining to Procházka and Fibich discussed in this contribution are among the relatively few documents showing mutual contact between these two figures. From the period after Fibich's return to Prague in 1874 we have no correspondence between them; they probably communicated frequently in person. In 1878 Fibich applied successfully for the position of choirmaster in the Russian orthodox church of St. Nicholas in the Old Town, ${ }^{16}$ whose first director was Procházka. As Vladimír Hudec wrote, ${ }^{17}$ this was probably the last service Procházka performed for Fibich before his departure for Hamburg. They corresponded later as well, as we know from a few preserved letters, but their contacts cannot be followed closely.

Transcription of Procházka's letter of 26 December 1873 to Fibich:

Můj drahý, milený príteli!

Toužebně jsem věru očekával Váš list, dychtiv jsa jen zvě-

děti, jak se Vám daři v novém Vašem povolání a zvěděti, máte-

li času, spomenouti se svých prátel, zde zanechaných. Zvěděl jsem

také již od sl. Hanušovy, že první doby Vašeho pobytu na Rusi ne-

byly právě príliš rủžové a litoval jsem Vás i ctěnou Vaši paničku

nemálo, co Vám bylo prestáti. Nyní snad jste již pretr-

pěli to nejhorší a protož jen vytrvejte jen v trpělivosti.

Žet hudební poměry ve Vilnè jsou tak bídné, nebyl bych si

pomyslil - je-li prec jen naděje, že to bude časem lépe? Ji-

nak by to pro Vás bylo trpkou zkouškou! -

Gratuluji Vám predevším ku krásnému, velmi lichotivé-

mu úspěchu, jejž Váš „Otello “v filharmonickém koncertu zís-

kal. Obdržel jste skrze sl. Hanušovu již bezpochyby veške-

ré listy s referáty. Účinek byl na veškeré obecenstvo pre-

kvapujicí - mně vadily poněkud prec trochu časté

cesury myšlenky a $v$ celku epigramatické prová-

dèní základních motivu. Lituji, že jste nemohl dílo své

sám slyšeti, byl byste také ucítil nutnost, některá

mista v ohledu orkestrálním změniti. Váš „Záboj a Slavoj“,

15 Of the prominent figures included besides Fibich let us mention e.g. August Wilhelm Ambros, Hans von Bülow, Antonín Dvořák, Robert Eitner, Karl Goldmark, Franz Liszt, Josef Mánes, Hans Richter, Hugo Riemann, Anton Rubinstein, Bedřich Smetana, and František Ženíšek. They cannot all be named here, because the album contains a total of 169 letters from various writers covering the period 1860-1888. A critical edition of the letters has been made in the framework of a grant from the National Museum and is now being prepared for publication.

He held this position until 1881.

17 Vladimír Hudec, Zdeněk Fibich (Prague, 1971), p. 48. 


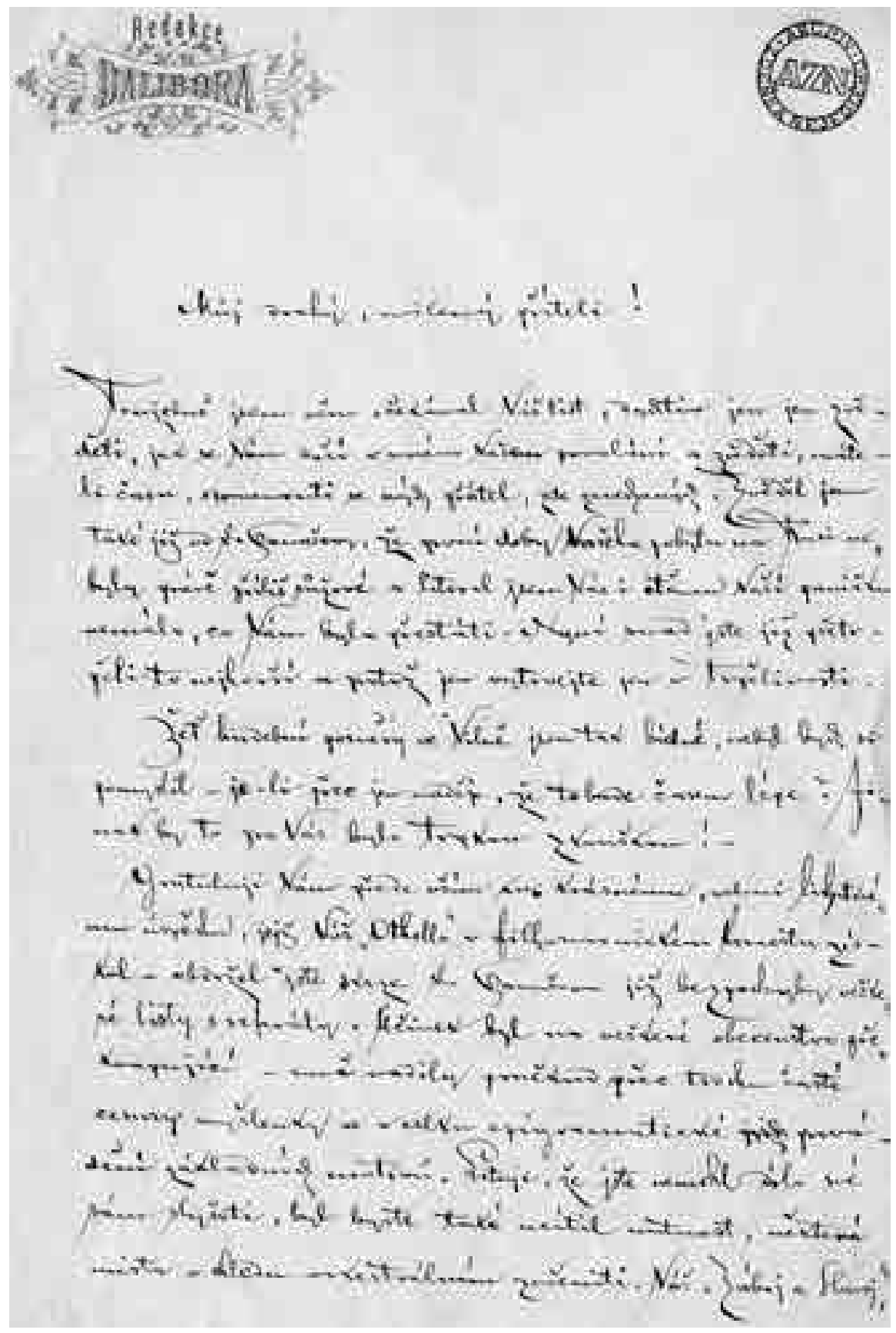

Ludevít Procházka's Letter to Zdeněk Fibich, Praha, on 26 December 1873, NM-ČMH shelf mark G 7096 


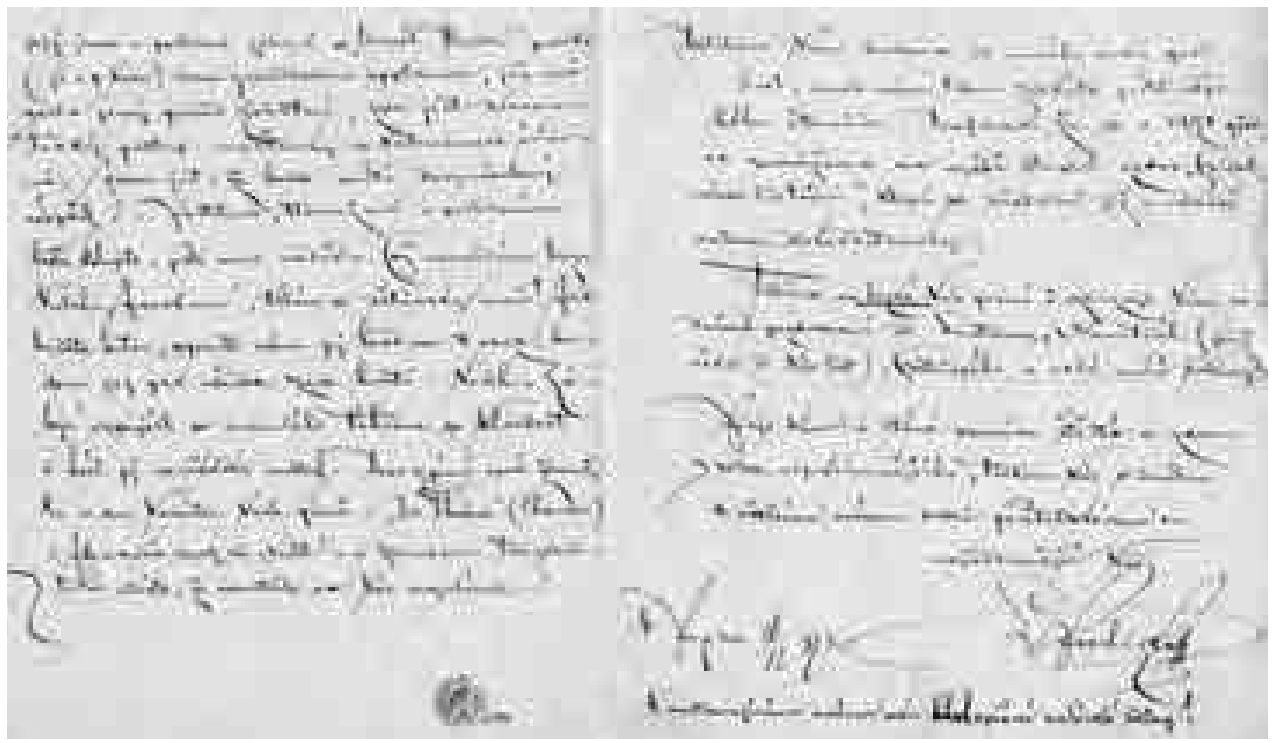

jejž jsme v poslední zábavě v „Umělecké besedě provedli

(já a p. Kaan) cum grandissimo applasu, již má

zcela jiný proud životní, zde jest drama-

tický postup myšlenky a kulminace účin-

ná. Jsem jist, že bude míti dvojnásobný

úspěch! - Partitura, kterouž mi v posledním

listu slibujete, ještě mne nedošla. Což neuvidím brzo

Vašeho „Jaroslava“, těším se dětinsky naň! Jak

budete hotov, upravte nám jej hned na 4 ruce, bu-

dem jej pak všude zase hráti. Vašeho „Zá-

boje" vypůjčll si minulého téhodne p. Kliebert

i hrál jej na několika místech. Dnes zpívá má ženuš-

ka u dr. Vanícka Vaše písně: „Die Thräne“"(Chamisso)

"Ich wandre durch die Nacht" - a Heineovu tragedii -

$Z$ toho vidíte, že neustále na Vás myslíme.

„Dalibora“ Vám budeme od nového roku posí-

lat, snad nám tam získáte ještě něja-

kého čtenářre. Doufáme, že se r. 1874 před-

ce zmůžeme na vyšši stupeň vzdor „Hudeb-

ním listưm “, které se důkladně již v národě

našem zdiskreditovaly. 
Těším se na brzké Vaše psaní $i$ vzkazuji Vám sr-

dečná pozdravení od Smetany, Novotného (jenž

čeká od Vás list), Hostinského a celé naší rodiny.

Přeje Vám i ctěné paničce štěstí a zdaru

z srdce nejupřimnějšího, tisknu Vás $v$ duchu

$k$ vrelému svému srdci prátelskému co

nejoddanější Váš

L. Procházka

V Praze 26/ 12873.

K nastavajícímu novému roku blahopřání naši celé rodiny!

Translated by David R. Beveridge

\section{Zdeněk Fibich und Jan Ludevít Procházka. Zu den ersten Aufführungen der Werke von Zdeněk Fibich}

\section{Zussamenfassung}

Der Beitrag bringt Informationen über zwei Quellen zum Leben und Werk von Zdeněk Fibich. Die erste ist eine bis jetzt (auch noch im thematischen Katalog von Vladimír Hudec) als verloren geltende Handschrift, die zweite ist ein diese betreffender Brief. Eine der bedeutenden Persönlichkeiten des Prager Musiklebens in den 60er und 70er Jahren des 19. Jahrhunderts war der Freund von Bedřich Smetana, der Pianist, Dirigent, Musikkritiker, Herausgeber, Musiklehrer und Komponist Jan Ludevít Procházka. Im Jahre 1871 hat er in Prag Zdeněk Fibich kennen gelernt und noch im selben Jahr im Rahmen der von ihm veranstalteten „Freien musikalischen Unterhaltungen“ die neuen Werke von Fibich zur Aufführung brachte. Er hat auch dem Werk Fibichs als Kritiker seine Aufmerksamkeit gewidmet. Im Jahre 1873, als Fibich in Wilna (Vilnius) gewirkt hat, blieben sie beide im brieflichen Kontakt. Im Tschechischen Museum der Musik ist ein Brief Procházkas erhalten, in dem er Fibich von dem Erfolg dessen beim philharmonischen Konzert in Prag aufgeführter symphonischer Dichtung Othello berichtet. Er erhebt einige kleine Einwände dem Werk gegenüber und erwähnt auch eine weitere symphonische Dichtung Fibichs, Záboj, Slavoj und Luděk, die er selbst gemeinsam mit Jindřich (Heinrich) Kàan in der Bearbeitung für Klavier vierhändig aufgeführt habe. Procházka schreibt auch, dass seine Frau Marta Procházková die Lieder Fibichs Die Thräne, Ich wandre durch die Nacht und Tragödie singt. Im Brief ist auch ein geplantes, schließlich nicht realisiertes Werk Fibichs erwähnt, nämlich die symphonische Dichtung Jaroslav, von der nur ein Motiv bekannt war. Das Autograph dieses Fragments führt der thematische Katalog Fibichs als 
verschollen an. Tatsächlich befindet sich dieses in einem Gedenkalbum von Dr. Ludevít Procházka, das das Nationalmuseum - Tschechisches Museum der Musik gemeinsam mit weiteren Handschriften aus der so genannten Morawetz-Sammlung im Jahre 2003 erworben hat (Sign. ČMH G 13 627).

Übersetzt von Vlasta Reittererová

\title{
Zdeněk Fibich a Jan Ludevít Procházka. K počátkům provádění Fibichových děl
}

\begin{abstract}
Shrnutí
Příspěvek prezentuje dva prameny k životu a dílu Zdeňka Fibicha. Jedním z nich je notový zápis, který byl doposud uváděn v Hudcově tematickém katalogu jako nezvěstný, druhý představuje dopis, který se k tomuto zápisu vztahuje. Jan Ludevít Procházka patřil k významným osobnostem pražského hudebního života v 60. a 70. letech 19. století. Byl klavíristou, dirigentem, hudebním kritikem, editorem, organizátorem, pedagogem i skladatelem a také přítelem Bedřicha Smetany. Se Zdeňkem Fibichem se seznámil záhy po Fibichově příchodu do Prahy v r. 1871 a v témže roce se zasloužil o uvedení jeho novinek v rámci Procházkou pořádaných Volných hudebních zábav. Fibichovo dílo sledoval i jako hudební kritik. V roce 1873, kdy Fibich pobýval ve Vilniusu, spolu navzájem korespondovali. V Českém muzeu hudby se dochoval Procházkův dopis, v němž informuje Fibicha o úspěchu jeho symfonické básně Othello, provedené na filharmonickém koncertu v Praze v době autorovy neprrítomnosti. V dopise uvádí některé své drobné výhrady k dílu a zmiňuje se o další symfonické básni Záboj, Slavoj a Luděk, kterou provedl s Jindřichem Kàanem v úpravě pro čtyřruční klavír. Uvádí také, že Marta Procházková zpívá Fibichovy písně Die Thräne, Ich wandre durch die Nacht a Tragödie. V dopise se nachází zmínka o zamýšleném, avšak nakonec nerealizovaném Fibichově díle - symfonické básni Jaroslav, z níž se dochoval pouze motiv. Jeho autografní zápis je uveden v tematickém katalogu jako nezvěstný. Ve skutečnosti se nachází v pamětním albu dr. Ludevíta Procházky, které v r. 2003 získalo Národní muzeum - České muzeum hudby spolu s dalšími rukopisy Morawtzovy sbírky (sign. ČMH G 13 627).
\end{abstract}

\section{Keywords}

Jan Ludevít Procházka; Zdeněk Fibich’s symphonic poems and songs. 